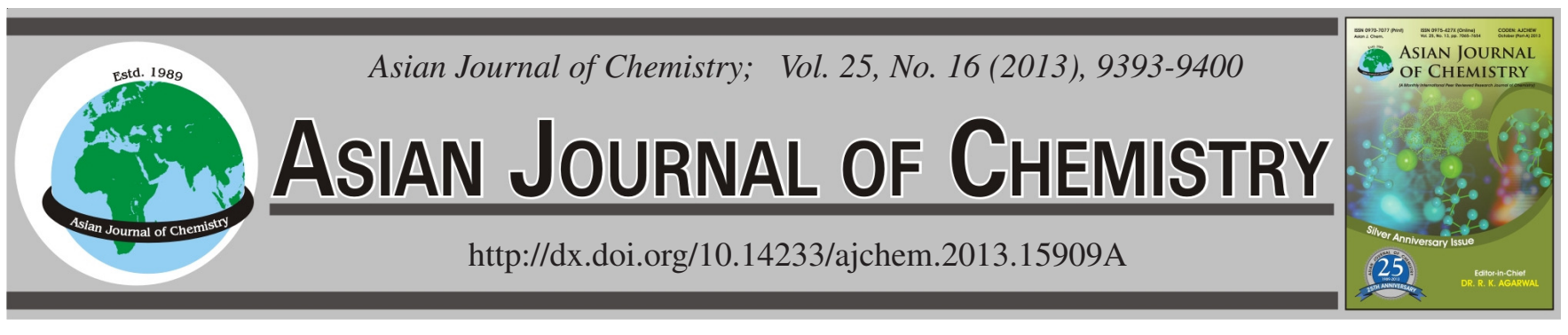

\title{
Chemical Properties of Treated Textile Dyeing Wastewater
}

\author{
FALAH H. HUSSEIN
}

Department of Chemistry, College of Science, Babylon University, Hilla, Iraq

Corresponding author: E-mail: abohasan_hilla@yahoo.com

\begin{abstract}
The main objective of this research was to observe and evaluate the chemical properties of photocatalytic treated textile industrial wastewater to evaluate reusing it again for different purposes such as agricultural irrigation, recreational uses, groundwater recharge, industrial reuse, environmental uses, non-potable urban uses, indirect potable reuse and direct potable reuse. Photocatalytic treatments carried out over a suspension of titanium dioxide (anatase or rutile) or zinc oxide under artificial irradiation. The progress of treatment stages was followed by using different techniques of analysis. The chemical parameters include total hardness (ppm), total alkalinity (ppm), chemical oxygen demand, biochemical oxygen demand, total organic carbon $(\%)$ and acidity $(\mathrm{pH})$. The concentration of major anions, such as, chloride $(\mathrm{ppm})$, phosphate $(\mathrm{ppm})$, nitrite $(\mathrm{ppm})$, nitrate $(\mathrm{ppm})$ were determined. The concentration of positive ions, such as, sodium (ppm), potassium (ppm), zinc (ppm), iron (ppm), cadmium (ppm), copper (ppm), nickel (ppm), cobalt (ppm) and manganese (ppm) and were also measured. Significance improvements of all these chemical parameters for all types of treated industrial wastewater were observed. Experimental results throughout the present study have indicated that the total hardness of real and simulated textile wastewater were reduced by more than $70 \%$ after photocatalytic treatments with titanium dioxide and zinc oxide. Alkalinity, which represents the existence of calcium carbonate or magnesium carbonate, is often related to hardness. Results of alkalinity concentration in different types of textile industrial wastewater dyes used in this study were in the range 37.54-76.66 ppm. The percentage of reduction of alkalinity was ranged between 10-22\% for the treated textile industrial wastewater dyes with the different types of catalysts used in this study. The $\mathrm{BOD}_{5} / \mathrm{COD}$ ratio of treated real wastewater reached $0.691,0.688$ and 0.711 as compared to 0.398 of the raw wastewater when anatase, rutile and zinc oxide used as photocatalyst respectively. Although the decolorization efficiency reaches $100 \%$, the total organic carbon removal efficiency did not reach that percentage. The results demonstrated $72-87 \%$ of TOC removal after $10 \mathrm{~h}$ of irradiation using titanium dioxide (anatase or rutile) and $92 \%$ when zinc oxide was used for the different textile industrial wastewater dyes. The initial $\mathrm{pH}$ of simulated and real textile industrial wastewater was in the range 8.41-12.90. All pH values for the photocatalytic treated textile industrial wastewater dyes with anatase; rutile and zinc oxide were reduced to $7.00 \pm 0.20$. Major anions e.g., chloride, phosphate, nitrite and nitrate were measured after and before photocatalytic treatments. The percentage of removal for these anions was exceeded $90 \%$ and in many cases reached $100 \%$. However, no significant changes were observed in the concentrations of the major cations, sodium and potassium, after and before photocatalytic treatments for the five textile industrial wastewater dyes used in this article. Real and simulated textile industrial wastewater dyes were also analyzed for zinc, iron, cadmium, copper, nickel, cobalt and manganese using atomic absorption spectrophotometer. No changes were observed in the concentrations of these metals after and before photocatalytic treatments. The heterogeneous photocatalytic degradation of real and another four prepared simulated textile industrial wastewater dyes viz.., (Vat yellow, Reactive black, Reactive blue and Cowboy dyes) were carried out on a laboratory scale using three commercial photocatalysts namely, anatase, rutile and zinc oxide.Comparison between the efficiency of the three photocatalysts indicated that their efficiency fell in the sequence: $\mathrm{ZnO}>\mathrm{TiO}_{2}$ (anatase) $>\mathrm{TiO}_{2}$ (rutile). However, the amount of zinc oxide required to reach the optimum activity is two times more than that for titanium dioxide (anatase or rutile) and the sequence was changed when the same concentration of mass was used (175 $\mathrm{mg} \mathrm{L}^{-1}$ ). The sequence in such case as follows: $\mathrm{TiO}_{2}$ (anatase) $>\mathrm{ZnO}>\mathrm{TiO}_{2}$ (rutile). Generally, the results of this study suggest that the treated wastewater is suitable for domestic, industrial and irrigational purposes.
\end{abstract}

Key Words: Photocatalytic degradation, Titanium dioxide, Zinc oxide, Wastewater treatment.

\section{INTRODUCTION}

Water crisis in Iraq is real crisis and could lead to disaster unless radical solutions are found quickly. Dams and reservoirs in Turkey and Syria have made the problem more badly. The level of water in the Tigris and the Euphrates has fallen by more than $60 \%$ over the past 20 years. Moreover, the decreasing trend of rainfall increases the effects of this crisis. Average annual rainfall in Iraq, is between 1,100 and 1,200 $\mathrm{mm}$. However, only 20-30\% of this average fell in the previous 
5 years. Water crisis in Iraq brings failed crops, sandstorms and elevated prices of saved drinking water. Imported packed drinking water in Iraq becomes more precious than exported oil.

Results presented in our previous study which also supported by Arab Science and Technology Foundation indicated that visible light (solar or artificial light)/ZnO and visible light (solar or artificial light) $/ \mathrm{TiO}_{2}$ systems could be efficiently used for the treatments textile industrial wastewater ${ }^{1,2}$. The results indicated that the used technique is an efficient technique for the treatments of industrial wastewater through a photocatalytic process and the transformation is practically complete in a reasonable irradiation time.

Textile industry effluents are extremely variable in composition and vary from plant to plant depending upon the processes used in the industry. Characteristics of a typical textile wastewaters are shown in Table- $1^{3-20}$.

\section{TABLE-1}

CHARACTERISTICS OF A TYPICAL TEXTILE WASTEWATER

\begin{tabular}{lcc}
\hline \multicolumn{1}{c}{ Parameter } & Minimum & Maximum \\
\hline $\mathrm{pH}$ & 5.5 & 10.5 \\
Temperature $\left({ }^{\circ} \mathrm{C}\right)$ & 33 & 45 \\
$\mathrm{BOD}(\mathrm{ppm})$ & 100 & 4000 \\
$\mathrm{COD}(\mathrm{ppm})$ & 150 & 10000 \\
TDS $(\mathrm{ppm})$ & 1500 & 6000 \\
TSS $(\mathrm{ppm})$ & 100 & 5000 \\
Total alkalinity (ppm) & 500 & 800 \\
Total Kjeldahl nitrogen $(\mathrm{ppm})$ & 70 & 80 \\
Oil and grease $(\mathrm{ppm})$ & 10 & 50 \\
Sulfides $(\mathrm{ppm})$ & 5 & 20 \\
Sulfates $(\mathrm{ppm})$ & 500 & 700 \\
Chloride $(\mathrm{ppm})$ & 200 & 6000 \\
Sodium $(\mathrm{ppm})$ & 400 & 2175 \\
Potassium $(\mathrm{ppm})$ & 30 & 50 \\
Zinc $(\mathrm{ppm})$ & 3 & 6 \\
Copper $(\mathrm{ppm})$ & 2 & 6 \\
Chromium $(\mathrm{ppm})$ & 2 & 5 \\
\hline
\end{tabular}

The chemical parameters which are important to evaluate the treated wastewater,include $\mathrm{pH}$, alkalinity/ppm, total hardness/ppm (TH), the concentrations of sulfate, phosphate, nitrate, chloride, calcium, magnesium and metals/ppm, chemical oxygen demand/ppm (COD) and dissolved oxygen/ppm $(\mathrm{DO})^{13}$

The most important parameters in textile industrial wastewater are COD, BOD, pH, SS, DS, chloride, sodium, fats, oil, nitrogen, phosphorus, sulphate and $\mathrm{TSS}^{14,15}$. Textile industry wastewater is characterized by high value of BOD, COD, $\mathrm{pH}$ and colour ${ }^{16}$. Textile industry wastewater is characterized byhighly visible colour and high value of BOD, COD and alkaline $\mathrm{pH}(9-11)^{17,18}$.

There are mainly two sources for metals in textile wastewater. These are the dye stuff and the impurities of chemicals such as caustic soda, sodium carbonate and salts which are used in the different stages of textile industry. According to World Health Organization the metals of most immediate concern are chromium, zinc, iron, mercury and lead ${ }^{19}$.

The aim of the present project is to investigate photocatalytic treatments of real and simulated textile wastewater using $\mathrm{TiO}_{2}$ and $\mathrm{ZnO}$ as photocatalysts with irradiation with artificial source of radiation and to evaluate the properties of treated of textile industrial wastewater to reuse it again for different purposes.

\section{EXPERIMENTAL}

Artificial photocatalytic reactor: Artificial irradiation experiments are performed in a homemade reactor. The reactor consists of graduated $1000 \mathrm{~cm}^{3}$ Pyrex glass beaker and a magnetic stirring setup. The radiation source was a Mazdan400W high pressure mercury lamp (Germany).The lamp was positioned perpendicularly above the reaction vessel.

All chemicals used for analysis in this study were analytical grade, supplied by BDH in a high purity $(\geq 99.9)$ and were used as supplied. $\mathrm{TiO}_{2} \mathrm{P}-25$ anatase purchased from Degussa, $\mathrm{TiO}_{2}$ rutile was obtained from Fluka and zinc oxide with $99.5 \%$ purity, supplied by Carlo ERBA.Real textile industrial wastewater dyes were collected at the mid of October 2010 from Textile Factory in Baghdad (Al- Kademeia). Samples of simulated dyes (Vat yellow, Reactive black and Reactive blue) were supplied from the same factory while Cowboy day was supplied by Al-Karama private factory in Baghdad.

Reaction procedure: The reaction procedure was described in details in a previous work ${ }^{20}$.

Chemical characterization of industrial wastewater: Another part of the double centrifuged textile industrial wastewater dyes was analyzed for total hardness (TH), total alkalinity, chemical oxygen demand (COD), biological oxygen demand (BOD), total organic carbons percentage (TOC \%), pH, concentrations of some anions (chloride, phosphate, nitrite and nitrate), concentrations of some cations (sodium and potassium) and the concentrations of some metals (zinc, iron, cadmium, copper, nickel, manganese and cobalt).

Hardness was obtained by EDTA titrimetric methods by following a procedure described before ${ }^{21}$. Total alkalinity was measured by titrimetric method. Chemical oxygen demand (COD) was determined by convectional reflux method, followed by colorimetric measurement at wavelength 420 and $600 \mathrm{~nm}$ depending on COD concentration. Dilution BOD test method was carried out for the $\mathrm{BOD}_{5}$ measurements. The total organic carbon (TOC) measurements were determined by the combustion method and analyzing the resultant $\mathrm{CO}_{2}$ in the combustion gases by using Shimadzu 5000A instrument. pH was determined using $\mathrm{pH}$ meter which has been initially standardized by using buffer solutions of known value before analysis . Chloride ion $\left(\mathrm{Cl}^{-}\right)$concentration was determined by Mohr's titration. Nitrate and nitrite concentration were measured by colorimetric method. Sodium and potassium ions concentrations were measured with flame photometer.

Heavy metal concentration was measured by Atomic Absorption Spectroscopy (SIMADZU, Model-AA3800/G). Known volume of real or stimulated textile wastewater was digested with analytical grade nitric acid. The digested textile industrial wastewater dyes was filtered into a $20 \mathrm{~cm}^{3}$ volumetric flask a the volume completed with distilled-deionized water and stored in a nitric acid pre-washed polyethylene bottle in the refrigerator prior to the chemical analysis. 


\section{RESULTS AND DISCUSSION}

Chemical characterization of industrial wastewater: Table-3 summarizes the chemical parameters which were measured for real and four types of simulated textile industrial wastewater at the beginning to characterize the wastewater.

The total hardness in different textile wastewater dyes was found to be in the range of 76.58-246.62 ppm. Total hardness simulated textile industrial wastewater Vat yellow dye (246.62 $\mathrm{ppm})$ was found higher than that for real textile wastewater dye (237.00 ppm).

The results of analysis of total alkalinity in the real textile wastewater was found $73.68 \mathrm{ppm}$ and in the range $37.54-76.66$ ppm for the simulated textile industrial wastewater dyes. The value of chemical oxygen demand (COD) of the studied textile industrial wastewater dyes varied between 142.70 and $225.084 \mathrm{ppm}$. The highest level was found in the real textile wastewater. Biological oxygen demand $\left(\mathrm{BOD}_{5}\right)$ varied from 94.560-118.340 ppm for simulated textile industrial wastewater dyes and was found $149.300 \mathrm{ppm}$ for real textile wastewater. The initial $\mathrm{pH}$ of simulated and real textile industrial wastewater was in the range 8.41-12.90. The highest level of $\mathrm{pH}$ was observed in the real textile wastewater dyes.

The ranges of the major anions concentrations in the studied textile industrial wastewater dyes were as follows: chlorides 28.57-68.49 ppm, phosphate nill-0.053 ppm, nitrite nill-0.001 ppm, nitrate nill-0.024 ppm. High concentration of sodium ions was observed in real textile industrial wastewater $(697.600 \mathrm{ppm})$, while the range of the same ion in the simulated textile industrial wastewater dyes was 4.524-18.730 ppm. Potassium concentration was also high in real textile industrial wastewater (44.83 ppm) compared with the concentration of potassium in simulated real textile industrial wastewater (0.214-0.335 ppm),

The values of metals in the real and the simulated textile industrial wastewater ranged as follows: zinc (ND-1.530 ppm), iron (ND), cadmium (ND-0.156 ppm), copper (ND-1.320 ppm), nickel (ND-0.104), cobalt (ND-0.031 ppm), manganese (ND-0.118).

Photocatalytic degradation of industrial wastewater using titanium dioxide (anatase): The decolorization efficiencies differ with the difference in type of dye used in textile industry. Under optimal conditions, the extent of decolorization was $100 \%$ after 42 min of irradiation for real textile industrial wastewater and between 10 and 35 min for prepared simulated industrial wastewater.

The results (Table-3) show that the photocatalytic treatments using anatase improved the chemical properties of the treated textile wastewater.

The results of total hardness values indicate that it was reduced after treatment with anatase by 70, 71, 71, 70 and $71 \%$ for real and simulated textile industrial wastewater dyes Vat yellow, Reactive black, Reactive blue and Cowboy, respectively.

The percentage of reduction of alkalinity for real and simulated textile industrial wastewater was ranged between $11-13 \%$ for the treated textile industrial wastewater dyes with the anatase.

Chemical oxygen demand (COD) for untreated textile industrial wastewater dyes of real and simulated textile industrial wastewater dyes Vat yellow, Reactive black, Reactive blue and Cowboy was 375.084, 260.324, 282.323, 242.700 and 275.643 ppm, respectively. Considerable reductions of COD concentration were observed after treatment with anatase The COD values were reduced to $112.434,66.654,70.574,83.556$ and $88.725 \mathrm{ppm}$. The removal percentage of COD for the five textile industrial wastewater dyes was ranged from 66 to $75 \%$.

The results indicate that BOD values were low compared with COD values for treated and untreated real and simulated textile industrial wastewater. Moreover, removal percentages of BOD values were also lower than that for COD removal. The reduction of BOD values in real and the four simulated textile industrial wastewater dyes were $48,51,49,41$ and $50 \%$, respectively.

TABLE-2

CHARACTERISTICS OF REAL AND SIMULATED TEXTILE WASTEWATER (CHEMICAL PARAMETERS)

\begin{tabular}{|c|c|c|c|c|c|}
\hline \multirow[b]{2}{*}{ Parameter } & \multicolumn{5}{|c|}{ Type of textile wastewater } \\
\hline & Real & $\begin{array}{l}\text { Simulated } \\
\text { Vat yellow }\end{array}$ & $\begin{array}{c}\text { Simulated } \\
\text { Reactive black }\end{array}$ & $\begin{array}{c}\text { Simulated } \\
\text { Reactive blue }\end{array}$ & $\begin{array}{l}\text { Simulated } \\
\text { Cowboy }\end{array}$ \\
\hline Total hardness (ppm) & 237.00 & 246.62 & 76.58 & 98.25 & 112.30 \\
\hline Total Alkalinity (ppm) & 73.68 & 76.66 & 37.54 & 40.36 & 45.69 \\
\hline Chemical oxygen demand (ppm) & 225.084 & 160.324 & 182.323 & 142.70 & 175.643 \\
\hline Biological oxygen demand (ppm) & 149.300 & 103.180 & 118.340 & 94.560 & 110.740 \\
\hline TOC $(\%)$ & 100 & 100 & 100 & 100 & 100 \\
\hline $\mathrm{pH}$ & 12.90 & 9.40 & 10.50 & 8.41 & 10.10 \\
\hline $\mathrm{Cl}(\mathrm{ppm})$ & 63.91 & 68.49 & 28.57 & 32.08 & 35.75 \\
\hline $\mathrm{PO}_{4}^{3-}(\mathrm{ppm})$ & ND & 0.002 & ND & 0.053 & ND \\
\hline $\mathrm{NO}_{2}^{-}(\mathrm{ppm})$ & ND & ND & ND & ND & 0.001 \\
\hline $\mathrm{NO}_{3}^{-}(\mathrm{ppm})$ & ND & ND & ND & ND & 0.024 \\
\hline $\mathrm{Na}(\mathrm{ppm})$ & 697.600 & 4.524 & 18.730 & 5.116 & 10.350 \\
\hline $\mathrm{K}(\mathrm{ppm})$ & 44.83 & 0.328 & 0.335 & 0.214 & 0.236 \\
\hline $\mathrm{Zn}(\mathrm{ppm})$ & 0.256 & ND & ND & ND & 1.530 \\
\hline $\mathrm{Fe}(\mathrm{ppm})$ & ND & ND & ND & ND & ND \\
\hline $\mathrm{Cd}(\mathrm{ppm})$ & ND & 0.073 & 0.156 & ND & ND \\
\hline $\mathrm{Cu}(\mathrm{ppm})$ & 0.270 & ND & ND & 1.320 & ND \\
\hline $\mathrm{Ni}(\mathrm{ppm})$ & 0.104 & $\mathrm{ND}$ & ND & ND & $\mathrm{ND}$ \\
\hline Co (ppm) & ND & 0.107 & $\mathrm{ND}$ & 0.031 & 0.006 \\
\hline $\mathrm{Mn}(\mathrm{ppm})$ & ND & ND & 0.118 & ND & 0.092 \\
\hline
\end{tabular}


The results (Table- 3 ) indicate that TOC \% removal was $72-87 \%$ for the five textile industrial wastewater dyes used in this project after $10 \mathrm{~h}$ of irradiation.

The results (Table-3) show that $\mathrm{pH}$ of untreated real and simulated textile industrial wastewater dyes appeared to lay between 8.41 and 12.90. After treatment the $\mathrm{pH}$ of all textile industrial wastewater dyes reduced toward neutral (6.8-7.1).

The results indicate that chloride has a percentage reduction of $80 \%$ in real textile wastewater dye and 83, 67, 100 and $71 \%$ for simulated Vat yellow, Reactive black, Reactive blue and Cowboy dyes, respectively.

Phosphate, nitrite and nitrate concentrations for untreated textile industrial wastewater dyes ranged from ND-0.053 ppm, ND-0.001 ppm and ND-0.024 ppm, respectively. After photocatalytic treatment in the existence of anatase none of the major anions (phosphate, nitrite and nitrate) were indicated.

The results (Table-3) indicate there were no significant changes in the concentrations of the major cations, sodium and potassium, after and before photocatalytic treatments for the five textile industrial wastewater dyes used in this project.

No significant changes were observed in the concentration of zinc, iron, cadmium, copper, nickel, cobalt and manganese before and after treatment of real and simulated textile industrial wastewater. Moreover, the concentrations of most of these metals were very low or non-detective.

Fig. 1 shows UV-visible spectra of decolorization of simulated textile industrial wastewater (Reactive black) in the existence of anatase.

Photocatalytic degradation of industrial wastewater using titanium dioxide (rutile): Under optimal conditions, the extent of decolorization was $100 \%$ after 370, 300, 120 and 90 min of irradiation for real industrial wastewater and prepared simulated textile industrial wastewater which are

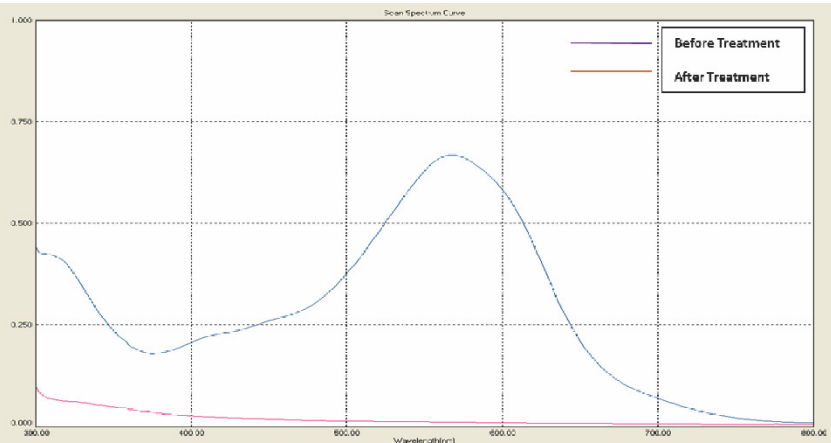

Fig. 1. UV-visible spectra of decolorization of simulated textile industrial wastewater (Reactive black) in the existence of anatase

Vat yellow, Reactive black and Reactive blue, respectively, when titanium dioxide (rutile) was used as photocatalyst. However, simulated 4 (Cowboy dyes) did not decolorized completely even when the time of irradiation was increased to $400 \mathrm{~min}$.

The results in Table-4 show that the photocatalytic treatments using rutile improved the chemical properties of the treated textile wastewater.

The total hardness in real and simulated textile wastewater textile industrial wastewater dyes were found to be in the range of 76.58-237.00 ppm (Table-4). The highest level of hardness was observed in simulated Vat yellow and that of minimum in simulated Reactive black. After treatment with rutile, the total hardness was found to be reduced up to level of $59 \%$ for real textile industrial wastewater dyes and 67, 74, 57 and $35 \%$ for simulated textile industrial wastewater dyes Vat yellow, Reactive black, Reactive blue and Cowboy, respectively.

The total alkalinity of real and simulated textile wastewater dyes was found to be in the range of 37.54-76.66 and

\begin{tabular}{|c|c|c|c|c|c|c|c|c|c|c|}
\hline \multirow[b]{4}{*}{ Parameter } & \multicolumn{8}{|c|}{$\begin{array}{l}\text { TABLE-3 } \\
\text { REATED WASTEWATER WITH ANATA }\end{array}$} & & \\
\hline & \multicolumn{10}{|c|}{ Type of textile wastewater } \\
\hline & \multicolumn{2}{|c|}{ Real } & \multicolumn{2}{|c|}{$\begin{array}{l}\text { Simulated } \\
\text { Vat yellow }\end{array}$} & \multicolumn{2}{|c|}{$\begin{array}{c}\text { Simulated } \\
\text { Reactive black }\end{array}$} & \multicolumn{2}{|c|}{$\begin{array}{c}\text { Simulated } \\
\text { Reactive blue }\end{array}$} & \multicolumn{2}{|c|}{$\begin{array}{l}\text { Simulated } \\
\text { Cowboy }\end{array}$} \\
\hline & 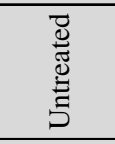 & 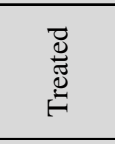 & 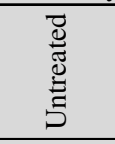 & 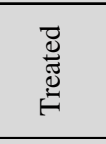 & 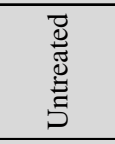 & 导 & 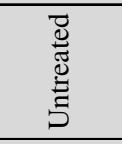 & 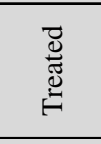 & 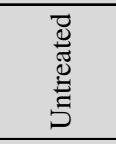 & 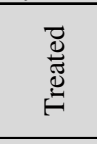 \\
\hline Total hardness (ppm) & 237.00 & 72.20 & 246.62 & 70.76 & 76.58 & 22.22 & 98.25 & 29.85 & 112.30 & 32.87 \\
\hline Total alkalinity (ppm) & 73.68 & 65.66 & 76.66 & 66.89 & 37.54 & 33.12 & 40.36 & 35.76 & 45.69 & 40.66 \\
\hline Chemical oxygen demand (ppm) & 375.084 & 112.434 & 260.324 & 66.654 & 282.323 & 70.574 & 242.700 & 83.556 & 275.643 & 88.725 \\
\hline Biological oxygen demand (ppm) & 149.300 & 77.656 & 103.180 & 50.987 & 118.340 & 60.354 & 94.560 & 55.546 & 110.740 & 55.241 \\
\hline$* \mathrm{TOC}(\%)$ & 100 & 72 & 100 & 87 & 100 & 80 & 100 & 84 & 100 & 75 \\
\hline $\mathrm{pH}$ & 12.90 & 7.10 & 9.40 & 7.06 & 10.50 & 6.96 & 8.41 & 7.10 & 10.10 & 6.88 \\
\hline $\mathrm{Cl}(\mathrm{ppm})$ & 63.91 & 12.34 & 68.49 & 11.76 & 28.57 & 9.42 & 32.08 & ND & 35.75 & 10.54 \\
\hline $\mathrm{PO}_{4}^{3-}(\mathrm{ppm})$ & ND & ND & 0.002 & ND & ND & ND & 0.053 & ND & ND & ND \\
\hline $\mathrm{NO}_{2}^{-}(\mathrm{ppm})$ & ND & ND & ND & ND & ND & ND & ND & ND & 0.001 & ND \\
\hline $\mathrm{NO}_{3}^{-}(\mathrm{ppm})$ & ND & ND & ND & ND & ND & ND & ND & ND & 0.024 & ND \\
\hline $\mathrm{Na}(\mathrm{ppm})$ & 697.600 & 694.883 & 4.524 & 4.622 & 18.730 & 19.231 & 5.116 & 4.982 & 10.350 & 9.873 \\
\hline $\mathrm{K}(\mathrm{ppm})$ & 44.83 & 43.83 & 0.328 & 0.422 & 0.335 & 0.342 & 0.214 & 0.212 & 0.236 & 0.232 \\
\hline $\mathrm{Zn}(\mathrm{ppm})$ & 0.256 & 0.228 & ND & ND & ND & ND & ND & ND & 1.530 & 1.492 \\
\hline $\mathrm{Fe}(\mathrm{ppm})$ & ND & ND & ND & ND & ND & ND & ND & ND & ND & ND \\
\hline $\mathrm{Cd}(\mathrm{ppm})$ & ND & ND & 0.073 & ND & 0.156 & 0.119 & ND & $\mathrm{ND}$ & ND & ND \\
\hline $\mathrm{Cu}(\mathrm{ppm})$ & 0.270 & 0.268 & ND & ND & ND & ND & 1.320 & 1.287 & ND & ND \\
\hline Ni (ppm) & 0.104 & 0.110 & ND & ND & ND & ND & ND & ND & ND & ND \\
\hline Co (ppm) & ND & ND & 0.107 & 0.110 & ND & ND & 0.031 & 0.033 & 0.006 & 0.004 \\
\hline $\mathrm{Mn}(\mathrm{ppm})$ & ND & ND & ND & ND & 0.118 & 0.112 & ND & ND & 0.092 & 0.100 \\
\hline
\end{tabular}


TABLE-4

CHEMICAL PROPERTIES OF TREATED WASTEWATER WITH RUTILE

\begin{tabular}{|c|c|c|c|c|c|c|c|c|c|c|}
\hline \multirow[b]{3}{*}{ Parameter } & \multicolumn{10}{|c|}{ Type of textile wastewater } \\
\hline & \multicolumn{2}{|c|}{ Real } & \multicolumn{2}{|c|}{$\begin{array}{l}\text { Simulated } \\
\text { Vat yellow }\end{array}$} & \multicolumn{2}{|c|}{$\begin{array}{c}\text { Simulated } \\
\text { Reactive black }\end{array}$} & \multicolumn{2}{|c|}{$\begin{array}{c}\text { Simulated } \\
\text { Reactive blue }\end{array}$} & \multicolumn{2}{|c|}{$\begin{array}{l}\text { Simulated } \\
\text { Cowboy }\end{array}$} \\
\hline & 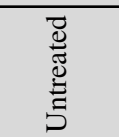 & 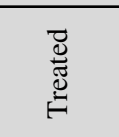 & 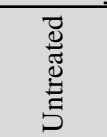 & 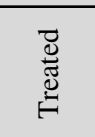 & 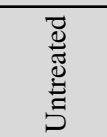 & 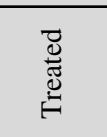 & 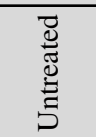 & 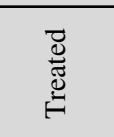 & 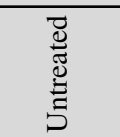 & 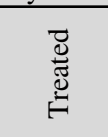 \\
\hline Total hardness (ppm) & 237.00 & 98.41 & 246.62 & 80.66 & 76.58 & 20.18 & 98.25 & 42.60 & 112.30 & 73.44 \\
\hline Total alkalinity (ppm) & 73.68 & 60.24 & 76.66 & 61.77 & 37.54 & 32.82 & 40.36 & 32.40 & 45.69 & 34.60 \\
\hline Chemical oxygen demand (ppm) & 225.084 & 128.330 & 160.324 & 80.241 & 182.323 & 84.552 & 142.70 & 102.211 & 175.643 & 188.440 \\
\hline Biological oxygen demand (ppm) & 149.300 & 84.550 & 103.180 & 62.422 & 118.340 & 72.424 & 94.560 & 60.223 & 110.740 & 82.845 \\
\hline *TOC $(\%)$ & 100 & 54 & 100 & 66 & 100 & 64 & 100 & 71 & 100 & 41 \\
\hline $\mathrm{pH}$ & 12.90 & 6.88 & 9.40 & 7.02 & 10.50 & 7.01 & 8.41 & 7.20 & 10.10 & 6.82 \\
\hline $\mathrm{Cl}(\mathrm{ppm})$ & 63.91 & 15.28 & 68.49 & 14.68 & 28.57 & 12.11 & 32.08 & 11.12 & 35.75 & 18.22 \\
\hline $\mathrm{PO}_{4}{ }^{3-}(\mathrm{ppm})$ & ND & ND & 0.002 & ND & ND & ND & 0.053 & ND & ND & ND \\
\hline $\mathrm{NO}_{2}^{-}(\mathrm{ppm})$ & ND & ND & ND & ND & ND & ND & ND & ND & 0.001 & ND \\
\hline $\mathrm{NO}_{3}^{-}(\mathrm{ppm})$ & ND & ND & ND & ND & ND & ND & ND & $\mathrm{ND}$ & 0.024 & ND \\
\hline $\mathrm{Na}(\mathrm{ppm})$ & 697.600 & 699.812 & 4.524 & 4.445 & 18.730 & 18.676 & 5.116 & 5.012 & 10.350 & 10.223 \\
\hline $\mathrm{K}(\mathrm{ppm})$ & 44.83 & 44.098 & 0.328 & 0.319 & 0.335 & 0.354 & 0.214 & 0.198 & 0.236 & 0.232 \\
\hline $\mathrm{Zn}(\mathrm{ppm})$ & 0.256 & 0.300 & ND & ND & ND & ND & ND & $\mathrm{ND}$ & 1.530 & 1.522 \\
\hline $\mathrm{Fe}(\mathrm{ppm})$ & ND & $\mathrm{ND}$ & ND & ND & $\mathrm{ND}$ & $\mathrm{ND}$ & ND & ND & ND & ND \\
\hline $\mathrm{Cd}(\mathrm{ppm})$ & ND & ND & 0.073 & ND & 0.156 & 0.101 & ND & ND & ND & ND \\
\hline $\mathrm{Cu}(\mathrm{ppm})$ & 0.270 & 0.268 & ND & ND & ND & $\mathrm{ND}$ & 1.320 & 1.308 & ND & ND \\
\hline $\mathrm{Ni}(\mathrm{ppm})$ & 0.104 & 0.110 & ND & ND & ND & ND & ND & ND & ND & ND \\
\hline Co (ppm) & ND & ND & 0.107 & 0.110 & ND & ND & 0.031 & 0.032 & 0.006 & 0.005 \\
\hline $\mathrm{Mn}(\mathrm{ppm})$ & ND & ND & ND & ND & 0.118 & 0.120 & ND & $\mathrm{ND}$ & 0.092 & 0.098 \\
\hline
\end{tabular}

*Measured after $10 \mathrm{~h}$ of irradiation.

32.40-61.77 ppm before and after treatment, respectively. The reduction percentage was $18 \%$ for real textile industrial wastewater dye and 19, 13, 20 and $24 \%$ for simulated textile industrial wastewater dyes Vat yellow, Reactive black, Reactive blue and Cowboy, respectively.

Chemical oxygen demand (COD) for untreated textile industrial wastewater dyes of real and simulated Vat yellow, Reactive black, Reactive blue and Cowboy dyes were 375.084, 260.324, 282.323, 242.700 and 275.643 ppm, respectively. Considerable reductions of COD concentration were observed after treatment with rutile The COD values were reduced to $128.330,80.241,84.552,102.211$ and $188.440 \mathrm{ppm}$.

The results in Table-4 indicate that BOD values were low compared with COD values for treated and untreated real and simulated textile industrial wastewater. Moreover, removal percentages of BOD values were also lower than that for COD removal. The BOD values in treated textile industrial wastewater dyes of real and simulated were found to be in the range 60.223-84.550 ppm.

TOC $\%$ was found to be reduced up to level of $54 \%$ for real textile industrial wastewater dyes and 66, 64, 71 and $41 \%$ for simulated textile industrial wastewater dyes Vat yellow, Reactive black, Reactive blue and Cowboy, respectively after $10 \mathrm{~h}$ of irradiation.

The results in Table-4 show that $\mathrm{pH}$ of untreated real and simulated textile industrial wastewater dyes appeared to lay between 8.41 and 12.90. After treatment the $\mathrm{pH}$ of all textile industrial wastewater dyes reduced toward neutral (6.82-7.20).

The results indicate that chloride has a percentage reduction of $76 \%$ in real textile wastewater dye and 79, 58, 65 and $49 \%$ for simulated textile industrial wastewater dyes Vat yellow, Reactive black, Reactive blue and Cowboy, respectively.
Phosphate, nitrite and nitrate concentrations for untreated textile industrial wastewater dyes ranged from ND-0.053 ppm, ND-0.001 ppm and ND-0.024 ppm, respectively. After photocatalytic treatment in the existence of rutilenone of the major anions (phosphate, nitrite and nitrate) were indicated.

The results in Table-4 indicate there were no significant changes in the concentrations of the major cations, sodium and potassium, after and before photocatalytic treatments for the five textile industrial wastewater dyes used in this project.

No significant changes were observed in the concentration of zinc, iron, cadmium, copper, nickel, cobalt and manganese before and after treatment of real and simulated textile industrial wastewater. Moreover, the concentrations of most of these metals were very low or non-detective.

Fig. 2 shows UV-visible spectra of decolorization of simulated textile industrial wastewater (Reactive black) in the existence of rutile.

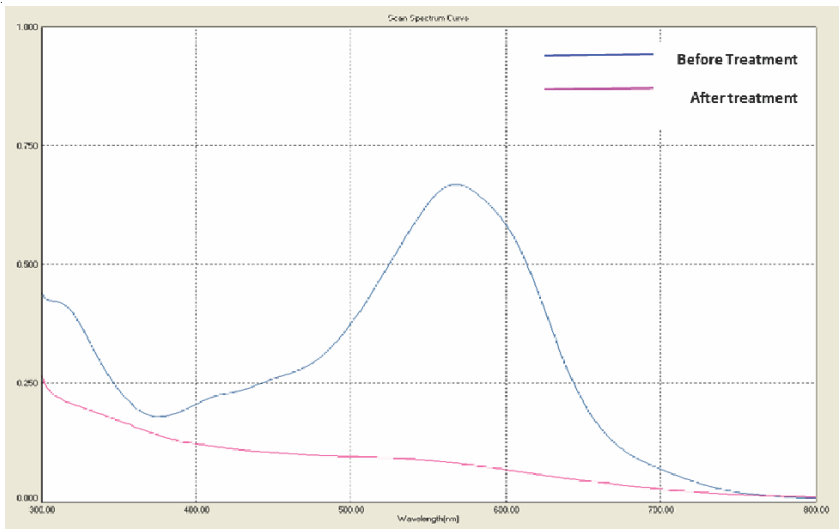

Fig. 2. UV-visible spectra of decolorization of simulated textile industrial wastewater (Reactive black) in the existence of rutile 
TABLE-5

CHEMICAL PROPERTIES OF TREATED WASTEWATER WITH ZINC OXIDE

\begin{tabular}{|c|c|c|c|c|c|c|c|c|c|c|}
\hline \multirow[b]{3}{*}{ Parameter } & \multicolumn{10}{|c|}{ Type of textile wastewater } \\
\hline & \multicolumn{2}{|c|}{ Real } & \multicolumn{2}{|c|}{$\begin{array}{c}\text { Simulated } \\
\text { Vat yellow }\end{array}$} & \multicolumn{2}{|c|}{$\begin{array}{c}\text { Simulated } \\
\text { Reactive black }\end{array}$} & \multicolumn{2}{|c|}{$\begin{array}{c}\text { Simulated } \\
\text { Reactive blue }\end{array}$} & \multicolumn{2}{|c|}{$\begin{array}{c}\text { Simulated } \\
\text { Cowboy }\end{array}$} \\
\hline & 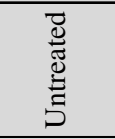 & ت己 & 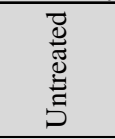 & 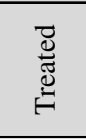 & 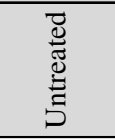 & تٕ & 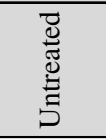 & 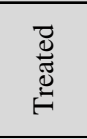 & 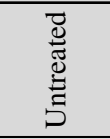 & 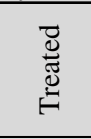 \\
\hline Total hardness (ppm) & 237.00 & 50.60 & 246.62 & 48.66 & 76.58 & 16.86 & 98.25 & 25.60 & 112.30 & 30.66 \\
\hline Chemical oxygen demand (ppm) & 225.084 & 98.60 & 160.324 & 60.42 & 182.323 & 59.55 & 142.70 & 70.12 & 175.643 & 62.61 \\
\hline Biological oxygen demand (ppm) & 149.300 & 68.61 & 103.180 & 45.61 & 118.340 & 52.88 & 94.560 & 48.60 & 110.740 & 50.12 \\
\hline$* \mathrm{TOC}(\%)$ & 100 & 78 & 100 & 88 & 100 & 84 & 100 & 84 & 100 & 82 \\
\hline $\mathrm{pH}$ & 12.90 & 7.01 & 9.40 & 7.02 & 10.50 & 6.98 & 8.41 & 7.20 & 10.10 & 6.80 \\
\hline $\mathrm{Cl}(\mathrm{ppm})$ & 63.91 & 9.12 & 68.49 & 10.12 & 28.57 & ND & 32.08 & ND & 35.75 & ND \\
\hline $\mathrm{PO}_{4}^{3-}(\mathrm{ppm})$ & ND & ND & 0.002 & ND & ND & ND & 0.053 & ND & ND & ND \\
\hline $\mathrm{NO}_{2}^{-}(\mathrm{ppm})$ & ND & ND & ND & ND & ND & ND & ND & ND & 0.001 & ND \\
\hline $\mathrm{Na}(\mathrm{ppm})$ & 697.600 & 696.880 & 4.524 & 4.496 & 18.730 & 18.276 & 5.116 & 4.984 & 10.350 & 10.543 \\
\hline $\mathrm{K}(\mathrm{ppm})$ & 44.831 & 44.654 & 0.328 & 0.298 & 0.335 & 0.321 & 0.214 & 0.221 & 0.236 & 0.241 \\
\hline $\mathrm{Zn}(\mathrm{ppm})$ & 0.256 & 0.332 & ND & 0.123 & ND & 0.111 & ND & 0,141 & 1.530 & 1.641 \\
\hline $\mathrm{Fe}(\mathrm{ppm})$ & ND & ND & ND & ND & ND & ND & $\mathrm{ND}$ & ND & ND & ND \\
\hline $\mathrm{Cd}(\mathrm{ppm})$ & ND & ND & 0.073 & ND & 0.156 & 0.162 & ND & ND & ND & ND \\
\hline $\mathrm{Cu}(\mathrm{ppm})$ & 0.270 & 0.282 & ND & ND & ND & ND & 1.320 & 1.297 & ND & ND \\
\hline Ni (ppm) & 0.104 & 0.112 & ND & ND & ND & ND & ND & ND & ND & ND \\
\hline Co (ppm) & ND & ND & 0.107 & 0.111 & ND & ND & 0.031 & ND & ND & ND \\
\hline $\mathrm{Mn}(\mathrm{ppm})$ & ND & ND & ND & ND & 0.118 & 0.122 & ND & ND & 0.092 & ND \\
\hline
\end{tabular}

*Measured after $10 \mathrm{~h}$ of irradiation.

\section{Photocatalytic degradationof industrial wastewater} using zinc oxide: Complete decolorization of textile industrial wastewater was obtained after 20, 7, 5 and 12 min of irradiation for prepared simulated textile industrial wastewater (Vat yellow, Reactive black, Reactive blue andCowboy dyes, respectively) and after $0.5 \mathrm{~h}$ for real industrial wastewater. These results were obtained when the concentration of zinc oxide was 350 $\mathrm{mg} \mathrm{L}^{-1}$

The results in Table- 5 show that the photocatalytic treatments using zinc oxide as photocatalyst improved the chemical properties of the treated textile wastewater.

The results of total hardness values indicate that it was reduced after treatment with zinc oxide by 79, 80, 78, 74 and $73 \%$ for real and simulated textile industrial wastewater dyes Vat yellow, Reactive black, Reactive blue and Cowboy, respectively.

The percentage of reduction of alkalinity for real and simulated textile industrial wastewater was ranged between 4-19\% for the treated textile industrial wastewater dyes when zinc oxide was used as photocatalyst.

Chemical oxygen demand (COD) for untreated textile industrial wastewater dyes of real and simulated 1, 2, 3 and 4 was $375.084,260.324,282.323,242.700$ and 275.643 ppm, respectively. Considerable reductions of COD concentration were observed after treatment with anatase The COD values were reduced to $98.600,60.420,59.550,70.120$ and 62.610 ppm.

The results indicate that BOD values were low compared with COD values for treated and untreated real and simulated textile industrial wastewater. Moreover, removal percentages of BOD values were also lower than that for COD removal. The reduction of BOD values in real and the four simulated textile industrial wastewater dyes were ranged between 49 and $56 \%$.

The results in Table-5 indicate that TOC \% removal was $78-88 \%$ for the five textile industrial wastewater dyes used in this project after $10 \mathrm{~h}$ of irradiation.

The results in Table-5 also show that $\mathrm{pH}$ of untreated real and simulated textile industrial wastewater dyes appeared to lay between 8.41 and 12.90. After treatment the $\mathrm{pH}$ of all textile industrial wastewater dyes reduced toward neutral (6.8-7.2).

The results indicate that chloride has a percentage reduction of $86 \%$ in real textile wastewater dye and 85, 100, 100 and $100 \%$ for simulated textile industrial wastewater dyes Vat yellow, Reactive black, Reactive blue and Cowboy, respectively.

Phosphate, nitrite and nitrate concentrations for untreated textile industrial wastewater dyes ranged from ND-0.053, ND0.001 and ND-0.024 ppm, respectively. After photocatalytic treatment in the existence of zinc oxide none of the major anions (phosphate, nitrite and nitrate) were indicated.

The results in Table-5 indicate there were no significant changes in the concentrations of the major cations, sodium and potassium, after and before photocatalytic treatments for the five textile industrial wastewater dyes used in this project.

No significant changes were observed in the concentration of zinc, iron, cadmium, copper, nickel, cobalt and manganese before and after treatment of real and simulated textile industrial wastewater. Moreover, the concentrations of most of these metals were very low or non-detective.

Fig. 3 shows UV-visible spectra of decolorization of simulated textile industrial wastewater (Reactive black) in the existence of zinc oxide. 
TABLE-6

BIODEGRADABILITY INDEX FOR REAL AND SIMULATED SAMPLES BEFORE AND AFTER TREATMENT

\begin{tabular}{lcccc}
\hline \multirow{2}{*}{ Type of wastewater } & \multicolumn{4}{c}{ Biodegradability index } \\
\cline { 2 - 5 } & Before treatment & After treatment with anatase & After treatment with rutile & After treatment with zinc oxide \\
\hline Real & 0.398 & 0.691 & 0.659 & 0.696 \\
Simulated Vat yellow & 0.396 & 0.765 & 0.778 & 0.755 \\
Simulated Reactive black & 0.419 & 0.855 & 0.857 & 0.888 \\
Simulated Reactive blue & 0.390 & 0.665 & 0.589 & 0.693 \\
Simulated Cowboy & 0.402 & 0.623 & 0.440 & 0.801 \\
\hline
\end{tabular}

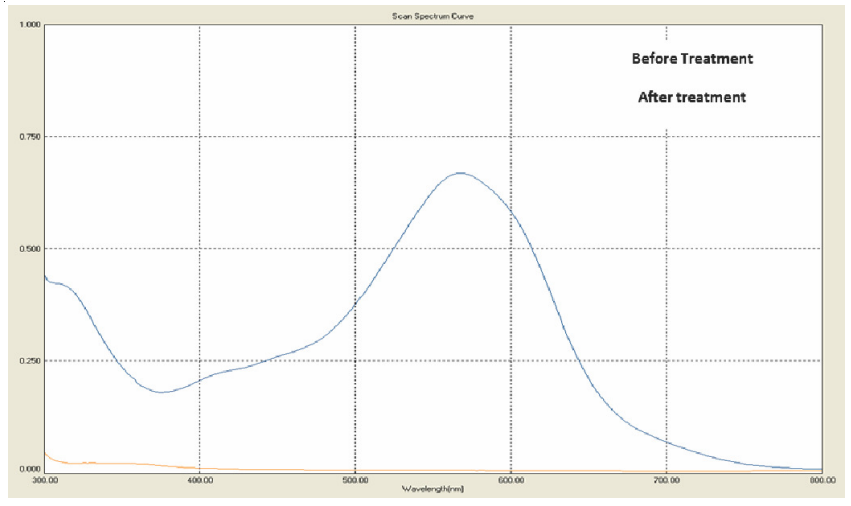

Fig. 3. UV-visible spectra of decolorization of simulated textile industrial wastewater (Reactive black) in the existence of zinc oxide

Biodegradability index: Textile wastewater is characterized by low value of biodegradability index $\left(\mathrm{BOD}_{5} / \mathrm{COD}\right)$ (approximately 0.36 ). The $\mathrm{BOD}_{5}$ to $\mathrm{COD}$ ratio of the different types of industrial wastewater was ranged between 0.390 and 0.419. After photocatalytic treatments with anatase, rutile and zinc oxide the biodegradability index was increased considerably. The results in Table-6 show that the biodegradability is doubled in some cases. These results indicate that the biodegradability of the industrial wastewater has been enhanced. Hence, the photocatalytic treatment processes appear to be useful in increasing the biodegradability of wastewater that contains refractory or toxic compounds.

The present project revealed that all photocatalysts were successful in improving chemical properties of industrial wastewater. However, different photocatalysts gave different activities.

Effect of type of catalyst on decolorization percentages of real and simulated dyes: It is clear from all obtained results that zinc oxide is the most effective catalyst and with all types of dyes the extent of decolorization reaches $100 \%$. The extent of decolorization was also $100 \%$ when anatase was used as photocatalyst but that needed more time than that needed when zinc oxide was used.However when rutile was used as photocatalyst, the time needed for complete decolorization was very long compared with anatase and zinc oxide. The extent of decolorization was $100 \%$ after 370, 300, 120 and 90 min of irradiation for real industrial wastewater and prepared simulated textile industrial wastewater which are Vat yellow, Reactive black and Reactive blue respectively, when titanium dioxide (rutile) was used as photocatalyst. However, simulated 4 (Cowboy dyes) did not decolorized completely even when the time of irradiation was increased to $400 \mathrm{~min}$.

The results indicated that the activity of different catalysts fell in the sequence:
$\mathrm{ZnO}>\mathrm{TiO}_{2}$ (Anatase) $>\mathrm{TiO}_{2}$ (Rutile)

This sequence was obtained when the optimum concentration of each catalyst was used $\left(1.750 \mathrm{mg} \mathrm{L}^{-1}\right.$ of anatase or rutile and $3.50 \mathrm{~g} \mathrm{~L}^{-1}$ of zinc oxide). When equal concentration of catalyst was used $\left(1.750 \mathrm{mg} \mathrm{L}^{-1}\right)$, the sequence was changed to:

$$
\mathrm{TiO}_{2-} \text { (Anatase) }>\mathrm{ZnO}>\mathrm{TiO}_{2} \text { (Rutile) }
$$

These findings are in good agreement with that reported before ${ }^{22}$.

Applications (potential and actual utilization of the project's output): The human eye can readily detect less than 1 ppm of most dyes. Hence, colour from textile industrial wastewater carries significant esthetic importance. The technique used in this project is very active forward decolorization of textile industrial wastewater and as a result it is a good way to let people agree to use the treated wastewater.

Textile industry is one of the largest and vital industrial sectors of most countries in the world. Textile industries release huge amount of effluents to aquatic systems. Discharging of industrial wastewater to aquatic systems is perhaps the most important sources of toxic contaminants in the environment.

The textile dyes were considered as major environmental pollutants and where, $15 \%$ of the dye is lost in the dyeing process and is released in the industrial wastewater ${ }^{23}$, so using this technology could save huge amount of water. Recycling process means reusing of industrial water after getting rid of specific contaminants. Reusing of treated industrial may follow one of the following three routes: Reusing it in the same process, if the treatment process is active enough to return it to same standard before using it in the industrial process. Reusing it in another industrial process, this needs water of less quality standard. Reusing it in irrigation or agriculture. Prevention of river water pollution by minimizing the emission of toxic substances. Same technique could be used for another type of industrial wastewater treatments. This technique could be also applied for domestic wastewater treatment.

\section{ACKNOWLEDGEMENTS}

The author gratefully acknowledged the financial support provided by Arab Science and Technology Foundation (ASTF). Sincere appreciation to all staff working at ASTF Baghdad Office is also acknowledged.

\section{REFERENCES}

\footnotetext{
F. Hussein and T. Abbas, Int. J. Chem. Sci., 8, 1353 (2010).

F. Hussein and T. Abbas, Int. J. Chem. Sci., 8, 1409 (2010).

C. Sahunin, J. Kaewboran and M. Hunsom, Sci. Asia, 32, 181 (2006).

S. Eswaramoorthi, K. Dhanapal and D.S. Chauhan, Environ. Technol. Awar. Series, 1, 1 (2008).
} 
5. F.S. Mehmet and Z.S. Hasan, J. Chem. Technol. Biotechnol., 77, 842 (2002).

6. I.A. Arslan, A.B. Isil and W.B. Detlef, Water Res., 36, 1143 (2002).

7. A. Bes-Piá, J.A. Mendoza-Roca, L. Roig-Alcover, A. Iborra-Clar, M.I Iborra-Clar and M.I. Alcaina-Miranda, Desalination, 157, 81 (2003).

8. A. Aleboyeh, Y. Moussa and H. Aleboyeh, Dyes Pigments, 66, 129 (2005).

9. G. Tchobanoglous, F.L. Burton and H.D. Stensel, Metcalf and Eddy, Wastewater Engineering: Treatment and Reuse, McGraw Hill, New York, edn. 4 (2003).

10. S.S. Kalra, S. Mohan, A. Sinha and G. Singh, Advanced Oxidation Processes for Treatment of Textile and Dye Wastewater: A Review, 2nd International Conference on Environmental Science and Development IPCBEE, Vol. 4 (2011).

11. Q. Mahmood, P. Zheng, E. Islam, Y. Hayat, M.J. Hassan, G. Jilani and R.C. Jin, Caspian J. Env. Sci., 3, 83 (2005)

12. Z. Carmen and S. Daniela, In ed.: T. Puzyn, Textile Organic DyesCharacteristics, Polluting Effects and Separation/Elimination Procedures from Industrial Effluents-A Critical Overview, Organic Pollutants Ten Years After the Stockholm Convention-Environmental and Analytical Update, ISBN: 978-953-307-917-2, InTech.

13. F. Hussein, M. Battol, Al-Adily, S. Sawsan, T. Al-Deen and M. Mayson Al-Taee, Yemeni J. Sci., 6, 31 (2005).
14. N. Tufekci, H.A. San, S. Aydýn, S. Ucar and H. Barlas, Fresenius Environ. Bull., 7, 795 (1998)

15. M. A. García-Morales, G. Roa-Morales, C. Barrera-Díaz, V.M. Miranda, P. Balderas-Hernández and T.B. Pavón Silva, Int. J. Electrochem. Sci., 8, 8752 (2013)

16. T. Robinson, G. McMullan, R. Merchant and P. Nigam, Bioresour. Technol., 77, 247 (2001).

17. V.M. Correia, T. Stephenson and S.J. Judd, Environ. Technol., 15, 917 (1994).

18. B. Manu and S. Chaudhari, Bioresour. Technol., 82, 225 (2002).

19. T. Boonyakarnkul, Geneva, Guidelines for Drinking Water Quality, World Health Organization, Geneva, Switzerland, edn. 3, Vol. 1 (1984).

20. F.H. Hussein, Asian J. Chem., 25, (2013).

21. AOAC, Official Methods of Analysis, Association of Official Analytical Chemists, Maryland, Association of Official American Chemists (AOAC), USA, edn. 17 (2002).

22. F.H. Hussein, Asian J. Chem., 24, 5427 (2012).

23. I. Arslan, I.A. Balcioglu and D.W. Bahnemann, Appl. Catal. B, 26, 193 (2000) 